\title{
Realizing the Effectiveness of Districts Administration at the Government of Pandeglang Regency, Banten Province, Indonesia
}

\author{
Arif Nugroho ${ }^{a} *$, Bambang Supriyono ${ }^{b}$, Tjahjanulin Domai ${ }^{\mathrm{c}}$, M.R. Khairul Muluk ${ }^{\mathrm{d}}$ \\ ${ }^{a}$ Serang Raya University, Serang, Banten, Indonesia \\ ${ }^{a}$ Brawijaya University, Malang, East Java, Indonesia
}

\section{INFORMASI ARTIKEL}

\section{Article history:}

Data submission : 12 September 2018

$1^{\text {st }}$ revision: 10 January 2019

Accepted: 17 April 2019

Available online: 02 May 2019

Keywords: local government, decentralization within cities, authority delegation, district institution

\begin{abstract}
This article discusses the fulfilment of the necessary condition of institutional elements in the District of Pandeglang. Especially in carrying out its capacity as an autonomous region as well as the administrative region of the province. The purpose of this article is to provide a recommendation model in delegating the authority of the Regent to the Head of District based on empirical conditions. This study uses a qualitative approach. The results showed that in Pandeglang District, the fulfilment of the necessary condition of the district institutions such as human resources and the budget was not directly proportional to the legal authority delegated by the Regent. In addition, in the aspect of the legal authority of the Head of District is still not accommodating enough on several aspects including legislation changes, regional characteristics, the spirit of institutional strengthening in public services, and the demands for orchestration of national development programs. Therefore, this article recommends a model in which the Pandeglang Regency Government is expected to conduct a series of district institutional arrangements or restructuring in order to realize the effectiveness of district administration as a supporting force in the administration of regional government.
\end{abstract}

2019 FIA UB. All rights reserved.

\section{Introduction}

Since the era of regional autonomy in 1999, district institutions are no longer an administrative area based on deconcentration principle and co-administration as in the past. However, the district has changed its position, especially since the enactment of the Regional Government Law Number 23 of 2014 in which the district is not only a tool of the autonomous region that receives the delegation of some authority from the regional head. Subdistricts are also domiciled as regional government administration units in the administration of general government affairs. This was a consequence of the construction of the Law that occupied the regional government with the perspective of the Agency Model and Local Choice simultaneously by Kavanagh (1982).
Furthermore, the fulfilment of the necessary condition elements of district institutions as the carrying capacity of the effectiveness of the implementation of regional governance can be interpreted as explained by Alderfer (1964) and Norton (1994:703-9) quoted from Muluk (2009) that in allocating downward power, in principle, is to arrange the administrative units or field stations and the establishment of local units with certain powers over specific areas of work, in other words, decentralization within cities to smaller units, so that the needs, responsibilities and decision making are closer to the community. Consecutivelly, Castell (2001) as quoted by Mugito (2012), argued that in term of district structuring through power-approach, the district capacity building can be done through granting the right to govern or make the district as an "autonomous region" in the governance system in Indonesia. 
The previous researches that are relevant to district institutions include Nannyonjo and Okot (2013) who examined the impact of decentralization and local government capacity for service efficiency in Uganda. Furthermore, Kemmochi et al (2016) in his study analyzed the condition of decentralization in cities based on questionnaire surveys. Emerick et al (2004) examined the decision of the district council to decentralize the services from the district headquarters in Serowe to the five sub-districts that existed in 1998, which was the first attempt in Botswana.

From the previous research, it can be seen that in general, the necessary condition elements as institutional support for the sub-district are considered important to be fulfilled in relation to the position of the sub-district as the division of the district and as the supporting capacity for the effectiveness of regional governance. Dharmawan (2008) explained that the necessary condition elements for supporting sub-district institutions consist of (a) legitimate authority, (b) funding (budget), (c) human resources (human resources), and (d) infrastructure.

From the description above, this article discusses the fulfilment of the necessary condition of an institutional district in Pandeglang Regency in carrying out its capacity as an instrument of autonomous regions and the administrative territory of general governance, as well as recommendations for the delegation of regent authority to district authorities.

\section{Theory}

Conyers, (1986) quoted by Ozmen, (2014:419) stated that decentralization is the transfer of authority to plan, make decisions and manage public functions from a higher level of government to any individual, organization or agency at a lower level.

Muthalib and Khan, (1983:2-18), explained that the understanding of the local government concept should be interpreted multi-dimensionally including: (a) social dimension; (b) economic dimension; (c) geographical dimension; (d) legal dimension; (e) political dimension; and (f) administrative dimension.

Decentralization concept under local authority level is called by decentralization environment, Burn et al, (1994) and decentralization in Norton City (1994:106-108). The purpose of their concept that allows the environment to articulate their needs brings strength closer to the people and draws more broadly from participants into the political system (Norton, 1994:106). Looking at the position of the district in Norton City, (1994:106) it is explained that the various authorities and affairs that should be handed over to the district government, appear to follow the model of decentralization within city, especially the pattern is said to be a general working towards the decentralization of functions throughout the new area on the subsidiarity principle (working leads to the general pattern of the decentralization function through the principle of branch formation (subsidiarity) which is based on a new area. Referring to the terms developed by Burns, et al.
(1994:81-189), the Subdistrict specifically leads to decentralized management or form of deconcentration of decentralization.

In the book of World Bank and United Cities and Local Governments (2008:33), Africa classified the local authorities according to the level of development of urbanization. For example, in reducing the urbanization ratings, Cameroon has urban communities such as special urban communes under urban commune and rural commune scheme. Classification in South Africa takes the form of an alphabetical hierarchy with categories $\mathrm{A}, \mathrm{B}$ and $\mathrm{C}$. This differentiation makes it easier to identify the most disadvantaged, and sometimes is called through an equalization process to focus on their development with the support of specific policies.

Understanding the district is a manifestation of the concept of decentralization within cities and the nature of management change as well as finding a decentralized environment as a strategy to provide a certain form. Burn et al, (1994:89). Understanding the district is a form of localization. Where at present there are many localizations that can be evaluated to what extent the localization is able to fulfil the objectives (a) physical accessibility; (b) openness; and (c) completeness. Flexibility is an approach that is also needed in managing a decentralized environment.

\section{Research Method}

This research was conducted using a qualitative approach. Data collection techniques carried out in this study are interviews, observations, review of documents which include provisions (law and policy), books, scientific articles, news in both print and electronic media, as well as the performance report of the authority of the district. The determination of the informants in this study is using purposive sampling technique.

Data analysis techniques in this study use interactive data analysis models from Miles, Huberman and Saldana (2014). The depiction of the data analysis model is carried out by the following steps: (a) data condensation; (b) data presentation (data display); and (c) conclusions drawing.

\section{Results and discussion}

\subsection{The Authority Operationalization and Necessary Condition as Autonomous Region Work Unit}

\subsubsection{The Authority for Regional Government Affairs}

The Pandeglang Regency Government, in applying the delegation of authority to the district head as seen from the existing arrangements, it is known that the nature of granting authority to the district is generic. It means that there is no specialization of authority between one district and another. On the one hand, there is a possibility of granting special authority from the districts whose working areas are included in the Special Economic Zones. Nordhold (1987:13) explained that the District Head as the lowest representative of the central 
government in his position represented the government policy towards the citizen. Furthermore, Wasistiono et al (2009:22) explained that the pattern of authority that can be delegated to the camat (district head) could be generic or specific. However, when referring to different characteristics, especially sub-districts that are in the national strategic program zone, then there should be authority delegated specifically to realize effectiveness and efficiency.

In this regard, if the authority delegated is generic without being balanced with the confirmation of more specific regional head regulations based on characteristics differentiation, coupled with the existence of problems of institutional adequacy such as the number of human resources and sub-district budgets that directly impact on the performance of delegated authority, it was indicated by (a) Regent Decree 138/ Kep.438-Huk/ 2014 of 5 licensing services, for building construction permit (IMB) services under $100 \mathrm{M}$ Square considered by some sub-districts not yet effective / still taken over by BPMPPTSP (Investment Board and OneStop Integrated Licensing Services) due to limited human resources; and (b) The non-optimal performance of delegated authority was allegedly due to the district that was more focused on fostering and monitoring and verifying village fund management.

In order to streamline the performance of the district head's authority in helping to realize the competitiveness of regional governance, it is deemed necessary to have the role of sub-district leaders who are able to initiate the authority that has been delegated by the regent, where the differences in the characteristics of subdistrict work areas are issues that should be elaborated by sub-district leaders. the goal of prospering the community and realizing the development goals of the district government through providing services with a concept that is closer to the community and the concept of implementing regional functions such as coordination, facilitation can be achieved.

\subsubsection{The Implementation of District Integrated Administration Service}

In the implementation of the PATEN administration (District Integrated Administration Service), there are 14 (fourteen) service items held in the District within the Pandeglang Regency Government. The building permit (IMB) service under 100 square meters in its implementation is still carried out by BPMPPTSP, whereas explicitly it has been regulated in the Regent Regulation No. 24 of 2013 that the service is the authority of the sub-district. Emerick et al (2004) from the results of his study of decentralized services in central district councils (CDC or District) in Botswana which made the first decision to decentralize services from district headquarters in Serowe in five subdistricts, but has not yet received service delegations. Decentralization is intended to determine the effect of productivity and efficiency. The author conducts interviews with senior officials and staff in five subdistrict/ sub-district offices.
Interviews may be considered anecdotal evidence, which discusses the perceptions of individuals who explain Botswana's unique socio-economic structure and political history in order to interpret the effects of administrative decentralization. Related to the problem of building permits under 100 square meters, there will be many perceptions, there is even some opinion about the authority of formalities only or a kind of explanation above about administrative decentralization that is not delegated. However, further findings of the current conditions in the field turned out to occur only in a number of sub-districts which have limited institutional adequacy including the competency and quantity of human resources as contained in the Permit to establish Building standards. Dharmawan (2008:4) explained that strengthening the sub-district institution is not only given legal authority, but the authority delegated is the only stimulant but the authority (delegation authority) obtained from the regent will be implemented if it is balanced with the support of the budget, human resources and infrastructure. Related to that if the core of the problem is only in the adequacy of the institution, actually, the regent can easily settle with the authority they have. If there is no attitude from the regent, there will be an omission from the regent for the incompatibility with the implementation of the provision.

\subsubsection{Coaching and Monitoring of Village Government}

Referring to Smith (1985:18), as quoted by Muluk, (2005:8), regarding to the village governance, it is explained that self-governing subdivisions have roots in the area in accordance with jurisdictional boundaries with areas that are not administered by the upper government agencies, and still regulated by politically formed institutions in the region. In other words, the village government as a self-governing institution tends to put more burden on the district in the process of guidance and supervision. The reason is that the village as a whole governmental parable is a legal community unit that has the same degree of autonomy as the local government, both in terms of decision-making in terms of development, budgeting up to the implementation of democratic procedures for the election of leaders. Under these conditions, the emergence of village egoism is very likely. It needs special handling through supervision and coaching. It is intended that the village can synergize with the sub-district.

The application of Law Number 6 of 2014 concerning village governance makes the function of the sub-district area not only as a supervisor representing the District Government in its working area but also as a village fund verifier. Smith (1985:199) states that regional administration or government is needed to ensure that other parts of the government work machine are supervised and controlled for the satisfaction of the central government or authority. This condition places regional office officers in special relations with the government or city authorities in their territory. In other words, the performance of supervision and supervision of the village government, especially related to village fund management, is a challenge that must be faced by a 
camat. Apart from the conditions of limited budget and human resources in the internal sub-district, also on the dynamics and complexity of the problems at the level of implementation at the village government level. From the results of the study it is known that the intended complexity is like (a) the conflict between the village and Pandeglang district over the establishment of 10 village development priority programs through the Circular of Pandeglang Regent Number 601/1474PPMPN/ 2017, so that there is reluctance from the village to realize development, and (b) The lack of ability of PTPKD (Village Financial Management Technical Executor) to technically operate the SISKEUDES (Village Financial System) online application.

\subsubsection{Authority Operationalization and Necessary Conditions as Administrative Region Work Unit General Government Implementation}

The implementation of general governance in the Pandeglang Regency Government is explained in the following figure:
Regulation) for the administration of the general government, it is known that, operationally, the district position assists the District Government and vertical agencies of the Directorate General of Politics and the General Government of the Ministry of the Interior. In the administration of the general government, the Camat is attributively the Head of the Forkopimka (District Leadership Coordination Forum). The position is tiered from the Central, Provincial and district/city levels. Meir (2010) stated that deconcentration transfers central government authority to lower levels within ministries. However, deconcentration also includes enabling provincial and district level bureaucracies to work closely with other sub-national groups within a democratic framework.

From the results of the study, it is known that up to now the RPP related to the verticalisation of Kesbangpol and the implementation of general government affairs have been submitted to the President, but have not yet been signed. Because there is a consideration that the estimated APBN capability will be used up to 10 Trillion when the PP (Government Regulation) is applied. Previously the RPP had entered the

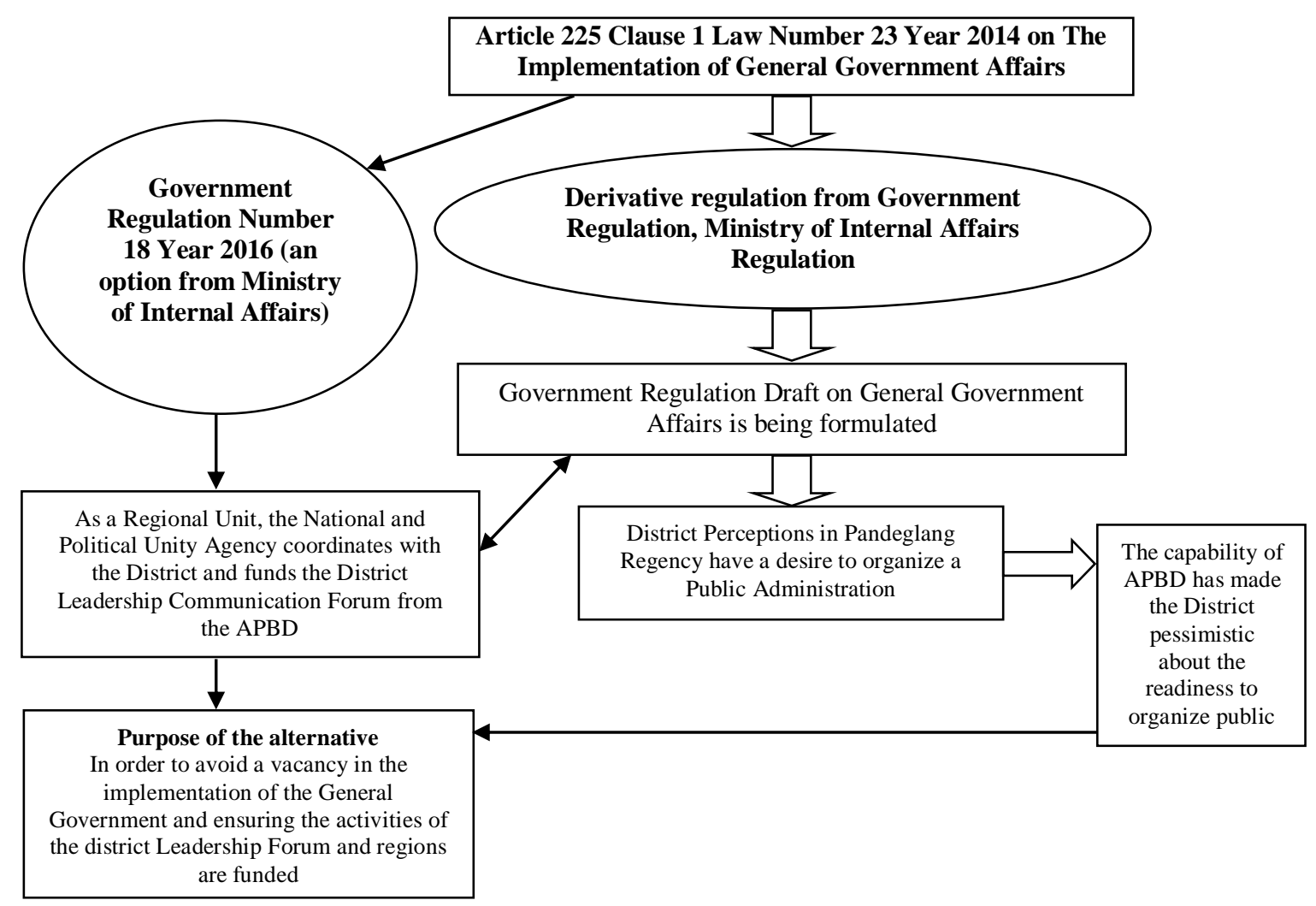

Picture 4.1. Existing condition of general government administration policy

Sources: Researcher analysis, 2017

Related to the picture above, currently, along with the implementation of Law Number 23 the Year 2014, and the Affirmation of Government Regulation Number 17 the Year 2018, there has been a change in the function and position of the District. Aside from being an instrument of an autonomous region, the district is also domiciled as an administrative area in the administration of general government. The direction of the policy formulated in the RPP (Draft Government harmonization level in the Ministry of Law and Human Rights and had been initialled by 4 four ministries, but after going to the President there was a limited meeting at the Cabinet Secretariat and until now it was still postponed. The average regional government is confused as the condition appear. In accordance with advice from the Ministry of Home Affairs, alternative steps that can be taken, especially in relation to funding Forkopimda and Forkopimka, are allocating from the 
Regional Budget (APBD) as mandated in the Minister of Home Affairs Regulation No. 33 of 2017 concerning the APBD General Guidelines for the year 2018.

The Government of Pandeglang Regency basically has the will and desire to implement the administration of the general government. However, the problem lays on the ability and readiness. Considering that the indicative ceilings in the district have been classified as the minimum, which is only Rp. 710,757,600.00 in 2017 and according to a different information only 500 million, even less than 500 million in previous years. In addition, the limitations of human resources also made pessimistic on the effectiveness of the implementation of the general government. The implementation will be effective if later government regulations and permendagri are stipulated but are not balanced with special budget allocations from the central government.

Related to the above statement, based on the results of the research, it is known that in Pandeglang Regency social problems often occur which are domains of general government affairs and have real implications for development. In this sense, the head of the district as the head of Forkopimka is being tested for his creativity and his action in the application of the principles of coordination, integration and synchronization in carrying out his capacity, the authority possessed as a regional instrument that is considered relevant to the essence of the mandate of the administration of general government as well as the authority of the security and public order. But on the one hand, the regent should also be present to provide solutions.

\subsection{Reporting and Evaluation on The Implementation of District Authority}

The reporting and evaluation practices on the implementation of district authority are describes as follows:
Based on the picture above and the study result, it is found that the evaluation mechanism as ruled is only effective in the first year after it is determined, then it does not, and there has not been any authority of the district head revoked so far. Then, from the contents of the monthly report, it was seen that the district head had not been optimal in carrying out the authority. It was indicated by the lack of coordination with the District Technical Implementation Unit (UPT), Health, Education, Agriculture, Maritime and Market. Basically, it needs to be done because it is included in the district head authority domain. Burn et al, (1994: 89) related to District Existence which is seen as localization explained that localisation refers to the physical relocation of service. it involves shifting from centrally located offices (often the hall) to sites within local communities. There are now over a hundred localization can be evaluated by the degree to which it is able to meet the objective of (1) physical accessibility (2) openness and (3) Comprehensiveness".

\subsection{Authority and Power Exercise}

\subsubsection{District Position based on Law number 23 Year 2014}

Based on the article 225 of Law Number 23 the Year 2014 , the districts are the administrators of general government and carry out governmental affairs as a part of district authority, which are not implemented by the work units of district governments. In this case, the district has a dual position as a device for the administration of the general administration and as an instrument of the autonomous region. Kavanagh, (1982) stated that there is two relations model between the central government and regional governments. First, the Agency Model, where the Regional Government is solely regarded as the executor by the central government. Second, a Partnership Model that emphasizes the broad freedom of local governments to

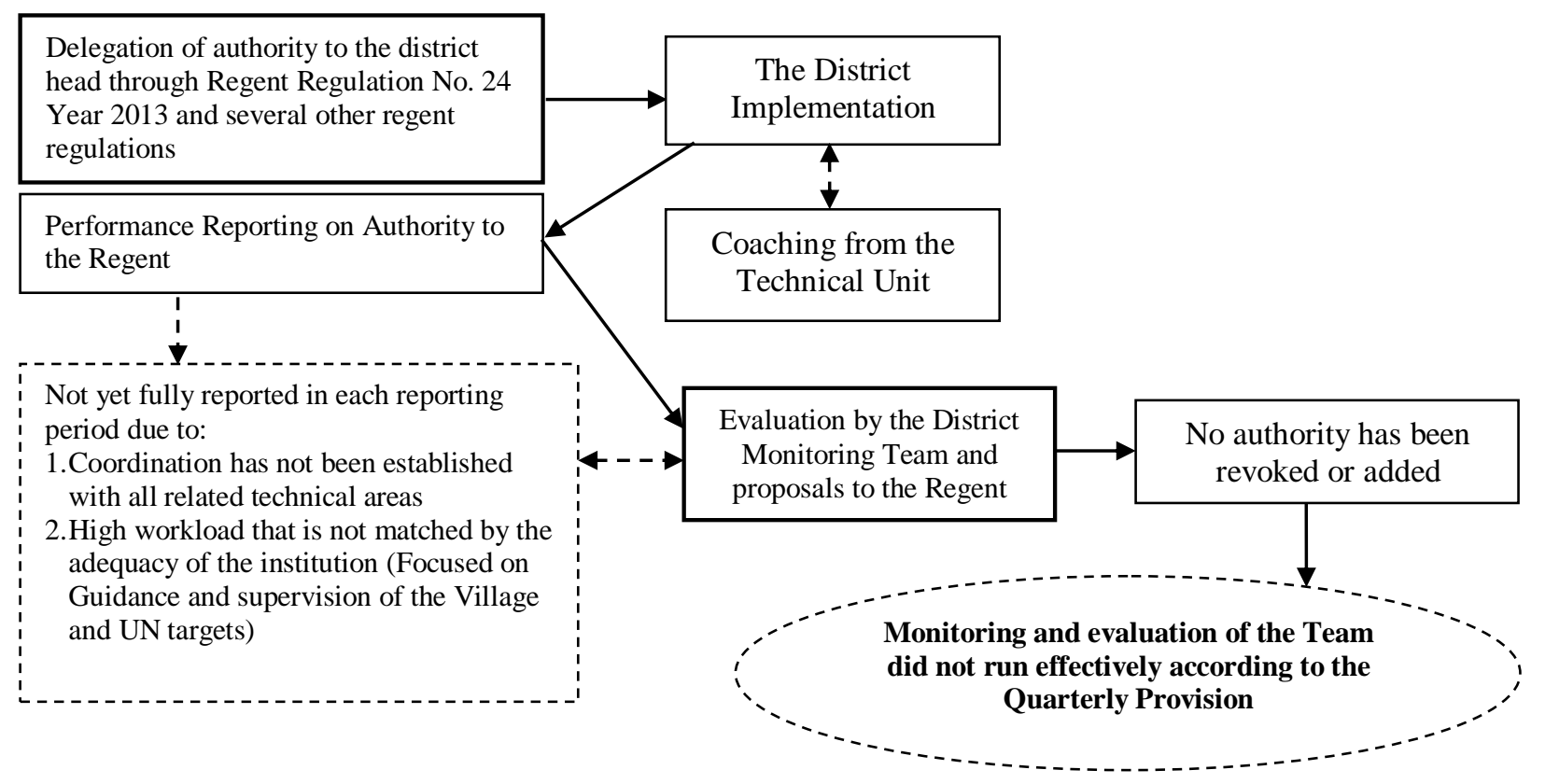

Picture 4.2. Existing Conditions of The Implementation of Reporting and Performance Evaluation of Camat authority Sources: Researcher analysis, 2017 
conduct "Local Choice".

The district as an autonomous regional apparatus, referring to the position of the district based on Law Number 23 the Year 2014, it is known that Pandeglang Regency has not provided enough room for the district to innovate and engaged in the development. The district is not given the opportunity to play a strategic role through the delegated authority. The district is only positioned on the domain of the administration. Therefore, only district heads who are creative and innovative are able to contribute to regional development.

\subsubsection{Structuring District Work Unit Organization and Strengthening Basic Service Role}

The enactment of Government Regulation Number 18 the Year 2016 is a momentum for the Pandeglang Regency Government to restructure the regional work unit. Based on the results of a study of variables including the population, area and number of villages, the Pandeglang Regency government categorized 35 sub-districts in typology $\mathrm{A}$. The regional work unit organizational structure was determined through Regional Regulation Number 6 the Year 2016 and Regent Regulation Number 66 the Year 2016 which regulates the position and district work procedures. Emerick et al (2004: 231) explained that decentralization is the transfer of power, planning and decisions from a single administrative centre to other places that contain several responsibilities that exceed the burden of the organization. It was intended to bring regional organization services closer to the community and improve efficiency and responsiveness.

Furthermore, the direction and strengthening of the policy on the regulation of the role of the sub-district head in basic services are described in the District RPP which is then ratified as Government Regulation Number 17 of 2018 concerning Districts. It is known from Article 11 Paragraph (7) that the delegation of the authority of the Regent to the District Head is based on mapping public services in accordance with the characteristics of the District and/or the needs of the local community. Smith (1985: 117) in the level of delegation of responsibility given to regional bureaucrats will affect the level of decentralization in the system. Regional Officers will get different tasks based on scheme agreement, power, function to examine including characteristics in the area. This is intended to bring different degrees of autonomy between regions. Furthermore, in Paragraph (2) it is explained that some of the government affairs that are delegated consist of licensing and non-licensing services. In the delegation of the intended authority, the Regency/city government is obliged to optimize service, externality, effectiveness and efficiency of government administration.

\subsection{Authority Delegation Model in the Recommended District}

The delegation of authority to the recommended district institutions. In delegating authority to the district, it needs to be accompanied by the fulfilment of the necessary conditions of the district institutions both in the capacity as an autonomous regional instrument and as an administrative area. In this case, the local

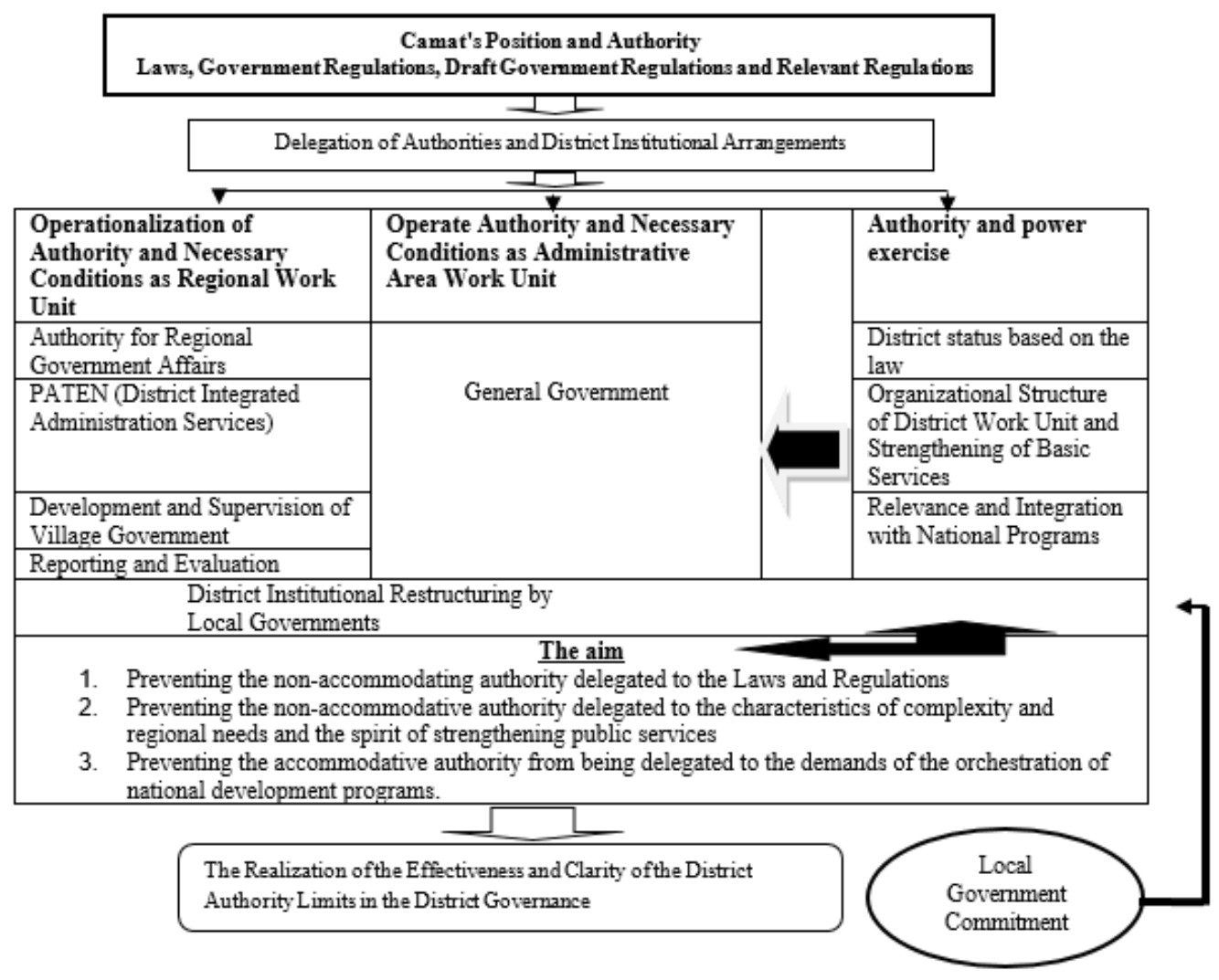

Picture 4. 3. The Regent Authority Delegation Model to the Recommended District Head Sources: Researcher analysis, 2017 
government can carry out the District Institutional Restructuring by exercising authority and power that pays attention to the District Position based on the Law, Strengthening Basic Services and Relevance and Integration with the National Program (Picture 4.3).

\section{Conclusion}

This research concluded that:

a) The effectiveness of district administration will be realized if the delegated authority: (1) Specifically legitimized the district territorial characteristics and needs; (2) quality of Human Resources; (3) Quality and quantity of institutional adequacy; and (4) commitment from the authority to consistently monitoring and evaluating the performance of authority;

b) The effectiveness of district administration will be realized if the regulation of the limits of authority delegated is accommodative to (1) changes in legislation; (2) territorial characteristics and spirit of institutional strengthening in public services; and (3) demand orchestration of national development programs;

c) Factors that need to be strengthened in delegation of authority include: (1) Assessment of district authorities that are more specific in accordance with the characteristics and needs of the community; (2) Restructuring the implementation of PATEN and other co-administration services including reliability of services; (3) Study of special district authorities located in zone of national strategy program; (4) Institutional adjustments to the mandate of the administration of general governance; and (5) Study of proportionality of institutional adequacy of districts; and

d) The ideal model of the devolution of authority of the Regional Head to the Subdistrict which is recommended is the Regional Government Action Plan for restructuring the subdistrict institutions in order to realize the district as an autonomous regional apparatus and the administrative administration of the general government which has an effective contribution in supporting the implementation of the Regional Government.

\section{References}

Burns, D. (1994). The Politic of Decentralization, Revitalising Local Democracy. Hongkong : MacMillan.

Dharmawan, H.A. (2008). Reposisis Ketata Pemerintahan Kecamatan. Bogor : Pusat Studi Pembangunan Pertanian dan Pedesaan.

Emerick, MN. (2004). DecentralisationOf Service Delivery As Adopted By The Central District Counsil At Bostawa. Journal Public Administration \& Development, 24(2) 225-240.

Kavanagh, D. (1982). Kebudayaan Politik. Cetakan Pertama. Jakarta. Penerbit PT. Bina Aksara.

Kemmochi, M. (2016). Research Concerning The State Of Decentralization Within Cities and The
Participation In City Planning. Journal of the City Planning Institute of Japan, 51(3).

Meir, B, Yossef, R. (2010). Morocco's Regionalization "Roadmap" and the Western Sahara. Ifrane : Al Akhawayn University, Journal On World Peace, 27(2).

Miles, H, \& Saldana, J. (2014). Qualitative Data Analysis, A Methods Sourcebook Edition 3. USA: Sage Publications.

Mugito (2012). Usaha - Usaha Penguatan Peran dan Fungsi Kecamatan di Era Otonomi Daerah. Jurnal Ilmiah Administrasi Publik, 13(1).

Muluk, M.R.K. (2005). Desentralisasi dan Pemerintah Daerah. Malang: Banyumedia Publishing. (2009). Peta Konsep Desentralisasi dan Pemerintahan Daerah. Surabaya : ITS Press -------. (2002). Desentralisasi Teori Cakupan dan Elemen, Jurnal Administrasi Negara, 2(02).

Nannyonjo, J. \& Okot, N. (2013). Decentralization, Local Government Capacity and Efficiency of Health Service Delivery in Uganda. Journal of African Development, 15(1).

Nordholt, N.S. (1987). Ojo Dumeh: Kepemimpinan Lokal dalam Pembangunan, Jakarta: Pustaka Sinar Harapan.

Norton, A. (1994). International Handbook of Local and Regional Government, A Comparative Analysis of Advenced Democracies, Adwarad Elgar, UK.

Ozmen, A. (2014). Notes To The Concept Of Decentralization. European Scientific Journal. 10(10), 1857- 7431.

Pandeglang Regent Regulation Number. 24 Year 2013 about Partly Regent Authority Delegation to the District Head.

Muttalib, M.A. \& M.A. Ali Khan. (1983). Theory of Local Government. New Delhi: Stereling Publishers. Diterjemahkan Masyarakat Ilmu Pengetahuan Indonesia.

Home Affairs Ministry Regulation Number 4 Year 2010 about Guidelines for District Integrated Administration Services.

Home Affairs Ministry Regulation Number 33 Year 2017 about Nomor 33 Tahun 2017 about the General Guidelines for Regional Budget (APBD) in 2018

Smith, B.C., (1985). Decentralization Teritorial Dimension of The State. Masyarakat ilmu Pemerintahan IPDN.

Pandeglang Regent Letter Number 601/1474DPMPD/2017 the 2017 Village Development Priority Program.

Pandeglang Regent Decree Number 138/Kep.438Huk/2014 about Formation of PATEN Team (District Integrated Administration Service).

Law Number 6 Year 2014 about Village Government.

Law Number 23 Year 2014 about Local Government.

Wasistiono, Sadu et al, 2009. Perkembangan Organisasi Kecamatan Dari Masa ke Masa. Bandung : Fokus Media.

World Bank, 2008. United Cities and Local Governments. Washington D.C. 